\title{
A gyermekkori uveitis klinikai jellemzői és terápiája
}

\author{
Kiss Judit dr. ${ }^{1}$ - Gaál Valéria dr. ${ }^{2}$ - Nyul Zoltán dr. ${ }^{1}$ - Mosdósi Bernadett dr. ${ }^{1}$ \\ ${ }^{1}$ Pécsi Tudományegyetem, Általános Orvostudományi Kar, Klinikai Központ, Gyermekgyógyászati Klinika, Pécs \\ ${ }^{2}$ Pécsi Tudományegyetem, Általános Orvostudományi Kar, Klinikai Központ, Szemészeti Klinika, Pécs
}

Bevezetés: Az uveitis a szem középső burkát alkotó képletek gyulladásával járó betegség, melynek incidenciája alacsony. Hátterében a leggyakrabban autoimmun megbetegedések és infekciók állnak. Az autoimmun kórképek közül a juvenilis idiopathiás arthritishez asszociáltan előforduló uveitis a leggyakoribb. A betegek jelentős része a lokális szemészeti kezelésre kevésbé mutat javulást, így szükség lehet immunmoduláló terápia bevezetésére.

Célkitüzés és módszer: Retrospektív vizsgálatunkban összesen 33 gyermek adatait elemeztük, akiket az elmúlt 5 év során a Pécsi Gyermekgyógyászati és Szemészeti Klinikán uveitisszel diagnosztizáltak és kezeltek.

Eredmények: A betegek átlagéletkora 9,3 $(0,3-17,8)$ év volt. A nemi megoszlásban lényeges különbséget nem észleltünk, de juvenilis idiopathiás arthritishez társult uveitis esetén női túlsúlyt találtunk. Az esetek 60\%-ában (20/33) sikerült a betegség háttérében etiológiai faktort azonosítani. 12 betegnél juvenilis idiopathiás arthritishez, két esetben Behcet-kórhoz, egy gyermeknél gyulladásos bélbetegséghez társultan alakult ki uveitis. 5 betegnél az uveitis hátterében infekció igazolódott. A kórkép az autoimmun betegségek többségében anterior, ezzel szemben infekciók esetén posterior lokalizációjú volt. A betegek többsége a lokális szerek mellett szisztémás terápiában is részesült. 3 gyermek szisztémás szteroidot kapott, 18 esetben betegséglefolyást módosító reumaellenes szer, per os metotrexátkezelés került bevezetésre. 13 betegnél a súlyos betegségaktivitásra való tekintettel biológiai terápiát (adalimumabinjekció) indítottunk. A gyógyszer bevezetését követően átlagosan 1,45 (0,75-2,5) hónapon belül remisszió alakult ki.

Következtetés: A gyermekkori uveitis kiemelt jelentőséggel bír. A korai diagnózis, a megfelelő terápia, a rendszeres kontrollvizsgálatok a társszakmák szoros együttmúködését igénylik.

Orv Hetil. 2019; 160(34): 1335-1339.

Kulcsszavak: uveitis, autoimmun kórképek, juvenilis idiopathiás arthritis, immunmoduláló terápia, biológiai terápia

\section{Clinical features and therapy of uveitis in childhood}

Introduction: Uveitis is characterized by inflammation of the middle layer of the eye. Its overall incidence is low. Autoimmune diseases and infections are the most common underlying diseases. Out of the autoimmune diseases, juvenile idiopathic arthritis is associated most frequently with uveitis. The topical ophthalmological treatment may fail in a significant proportion of the patients and immunomodulatory therapy may be required.

Aim and method: In a retrospective study, data of 33 children diagnosed and treated with uveitis at the Department of Pediatrics and Ophthalmology, University of Pécs during the last 5 years were collected and analyzed.

Results: The mean age of the patients was $9.3(0.3-17.8)$ years. Boys and girls were equally affected with an exception of patients with juvenile idiopathic arthritis where female predominance was found. An underlying disease could be identified in $60 \%$ of the cases $(20 / 33)$. Uveitis was associated in 12 patients with juvenile idiopathic arthritis, in 2 patients with Behcet's disease and in a single case with inflammatory bowel disease. Infections have been proven in 5 patients. The autoimmune diseases caused an eye inflammation typically in anterior localization, in contrast to the infections that resulted in posterior uveitis. The majority of the patients required systemic treatment. 3 of them received systemic corticosteroid and 18 patients methotrexate as disease-modifying antirheumatic drug. 13 children with severe disease activity required biological therapy (adalimumab injection). Remission could be achieved in 1.45 (0.75-2.5) months.

Conclusion: Pediatric uveitis is of great importance. Early diagnosis, adequate therapy and follow-up require multidisciplinary cooperation.

Keywords: uveitis, autoimmune diseases, juvenile idiopathic arthritis, immunomodulatory therapy, biological therapy

Kiss J, Gaál V, Nyul Z, Mosdósi B. [Clinical features and therapy of uveitis in childhood]. Orv Hetil. 2019; 160(34): $1335-1339$.

(Beérkezett: 2019. február 24.; elfogadva: 2019. április 3.) 


\section{Rövidítések}

ANA = (antinuclear antibody) antinukleáris antitest; die = nap; DMARD $=$ (disease-modifying antirheumatic drug) betegséglefolyást módosító reumaellenes szer; IBD $=$ (inflammatory bowel disease) gyulladásos bélbetegség; JIA = juvenilis idiopathiás arthritis; SLE = (systemic lupus erythematosus) szisztémás lupus erythematosus; $\mathrm{TNF} \alpha=$ (tumor necrosis factor alpha) tumornekrózisfaktor-alfa

A szem középső burkát, az uveát alkotó képletek (iris, corpus ciliare, choroidea) gyulladását uveitisnek nevezzük.

\section{Incidencia, prevalencia}

A kórkép átlagos incidenciája és prevalenciája világszerte változó, mivel a hátterében álló esetleges autoimmun megbetegedések és infekciók eltérő gyakorisággal fordulnak elő. A betegség incidenciája megközelítőleg $50 / 100000$ fó, prevalenciája 100/100 000 fó. A gyermekkori uveitis viszonylag ritka, átlagosan az esetek 5-10\%-a. A kórkép jelentőségét hangsúlyozza, hogy az uveitis a gyermekkori vakság 10\%-áért felelős [1].

\section{Osztályozás}

A betegség többféle szempont szerinti felosztása lehetséges. Az anatómiai lokalizáció szerint az uveitis anterior (iritis, iridocyclitis), intermedier (pars planitis), posterior (choroiditis és/vagy retinitis, neuroretinitis) uveitisként, valamint e struktúrákat együttesen érintő panuveitisként osztályozható. A kórlefolyás alapján a gyulladás lehet akut (hirtelen kezdet, kevesebb mint három hónapig tart), rekurráló (ismétlődő epizódok és tünetmentes időszakok váltakozása több mint három hónapon keresztül), illetve krónikus (több mint három hónapig perzisztáló vagy a kezelés befejezését követő három hónapon belül visszatérő) [2].

\section{Etiológia, patomechanizmus}

Az uveitis etiológiája heterogén. Okozhatják infekciók (Toxoplasma, Toxocara, Bartonella spp., Lyme-borreliosis, varicella zoster, herpes simplex stb.), fontos azonban hangsúlyoznunk, hogy a szem immunprivilegizált szerv, így a gyulladásos folyamatok sokszor csak a fertőzés után hosszú idővel alakulnak ki. Megjelenhet szisztémás autoimmun betegséggel társultan is, az esetek közel felében azonban idiopathiás, a kórok ismeretlen marad. Ismertek ún. „utánzó” szindrómák is (retinoblastoma, melanoma malignum, leukaemia, lymphoma, intraocularis idegen test, ideghártya-leválás stb.), melyek az uveitishez hasonló tüneteket okozhatnak, felhívva a figyelmet a differenciáldiagnosztika jelentőségére.

A gyermekkori uveitis gyakran autoimmun betegségekhez asszociáltan jelentkezik, a legtöbbször juvenilis idiopathiás arthritishez (JIA) társul. A kórkép a JIA leggyakoribb extraarticularis kísérő betegsége [3]. A JIA különböző alcsoportjaiban eltérő arányban fordul elő uveitis. A leggyakrabban észlelt oligoarticularis formában az esetek közel 30\%-ában krónikus anterior uveitis alakul ki, mely a legsúlyosabb szemészeti szövődményeket vonja maga után. Az elsősorban idősebb fiúgyermekeknél jelentkező enthesitisasszociált forma esetében akut anterior uveitis fejlődhet ki. A súlyos ízületi aktivitással jellemzett poliarticularis alcsoportban csupán 2-5\%-ban, míg a szisztémás alosztály esetén 1-2\%-ban alakul ki krónikus anterior uveitis.

A JIA-betegek 12-38\%-ában a kórkép az arthritis kezdetétől számított 7 éven belül alakul ki, az esetek 3-7\%ában azonban a szemészeti eltérések az ízületi tünetek jelentkezése előtt is észlelhetők [4]. Súlyosabb betegséglefolyás várható fiatalkori kezdet, férfinem, antinukleárisantitest (ANA)-pozitivitás esetén, illetve ha a szemészeti tünet megelőzi az ízületi gyulladást, vagy azzal közel egy időben jelentkezik [5].

A JIA komplex genetikai hátterü betegség, melynél monogénes vagy mendeli öröklésmenet nem igazolódott [6]. Habár a JIA és az uveitis közötti szoros összefüggés már régóta ismert, a szemben zajló gyulladás pontos oka nincs teljesen feltárva. A nem fertőzéses eredetű uveitist T-sejt mediálta betegségnek tekintjük, melyben a $\mathrm{T}_{\mathrm{H}} \mathrm{l}$-es és $\mathrm{T}_{\mathrm{H}}$ 17-es alosztályoknak van kiemelt jelentőségük. A CD4-pozitív lymphocyták mellett CD20-pozitív B-sejtek, makrofágok és plazmasejtek jelenléte is kimutatható [3]. A JIA-asszociált uveitis esetében feltételezik az intraocularis proteinekkel (például retinolt kötő protein-3, $S$-arresztin, tirozinázhoz kötődő proteinek) szembeni tolerancia elvesztésének kóroki szerepét [6].

\section{Diagnózis, klinikai jellemzők}

A kórkép diagnózisa és súlyosságának megítélése réslámpás vizsgálattal történik, melyet látásélesség- és szemfenékvizsgálattal, illetve nagyobb gyermekeknél az intraocularis nyomás mérésével kell kiegészíteni.

Akut anterior uveitis esetén szempirosság, heves, közelre nézéskor fokozódó, a környező területekre kisugárzó szemfájdalom, valamint fénykerülés, látáscsökkenés jellemző. Réslámpás vizsgálat során ciliaris izgalom, paralimbalis livid gyưrü észlelhető, a gyulladás következtében a megnövekedett fehérjetartalom miatt a csarnokvíz opaleszkál (Tyndall-jelenség). A gyulladásos exsudatio a cornea hátsó felszínén precipitátumként lerakódik.

Kiemelendő, hogy krónikus anterior uveitis esetében a tünetek kevésbé kifejezettek, a fájdalom kisebb mértékü vagy nem jellemző, a látásélesség lassan csökken. Réslámpás vizsgálat során a Tyndall-jelenség mellett finom, lisztszerú precipitátumok láthatók. Gyakran már az első szakvizsgálat során az iris pupillaris szélének lencséhez történő lenövése észlelhető.

Intermedier uveitis esetén a tünetek szegényesek. Az üvegtestbe kerülő izzadmány miatt úszkáló borússágok, 
homályok látása, látásromlás, alkalmazkodási zavar előfordulhat. Objektív tünetként az üvegtestben észlelhető sejtes szóródás mellett az exsudatum jellegzetes alakot (hópadképződmény, hógolyóképződmény) ölthet. A retina vénái behüvelyezettek lehetnek a lymphocyták lerakódása miatt.

Posterior uveitis során a fó tünet a látótérkiesés a gyulladásos góc lokalizációjának megfelelően. A centrumban elhelyezkedő góc esetén torz látás, látáscsökkenés alakulhat ki. Szemészeti szakvizsgálat során szürkésfehér színú, életlen szélű, különböző nagyságú, a retina szintjéből kiemelkedő gyulladásos gócok ábrázolódnak, melyek körül a retina ödémás $[7,8]$.

$\mathrm{Az}$ uveitis a legmodernebb terápiás lehetőségek ellenére még napjainkban is súlyos szemészeti szövődményekkel gyógyulhat. JIA-asszociált uveitis esetén a leggyakrabban posterior synechia, szürke hályog, band keratopathia, zöld hályog, maculopathia alakulhat ki. A gyermekkori esetek akár 25-30\%-ában maradandó látáskárosodással számolhatunk [1].

\section{Terápia}

A kezelés fó célja a tartós remisszió elérése. A gyógyszeres terápia megválasztása a betegség alcsoportja, tünettana, valamint aktivitása szerint történik.

Igazolt infekciók esetén antimikrobás kezelés indokolt, kis dózisú lokális vagy súlyosabb esetben szisztémás szteroiddal kiegészítve.

A JIA-asszociált uveitis valamennyi formájában lépcsőzetesen felépített terápia szükséges [9]. A szemészeti gyulladásra az első vonalbeli kezelést a lokálisan alkalmazott kortikoszteroidok jelentik [9-11]. A szteroidtartalmú szemcseppek hosszan tartó, gyakori használata azonban rizikófaktort jelent másodlagos szürke hályog, zöld hályog kifejlődésére. A gyulladásos folyamat megfékezése mellett a lokális terápiában alapvető jelentőségű a gyulladás okozta lenövések megakadályozása hosszú hatású pupillatágító készítménnyel (például Homatropin 0,1\%-os szemcsepp).

A lokális szteroidok önmagukban is hatásosak lehetnek, de súlyos vagy látást veszélyeztető állapot esetén szisztémásan adott kortikoszteroidok alkalmazása is szükséges. Súlyos formában ún. lökésterápiaként nagy dózisú intravénás metilprednizolon-kezelést (10-30 $\mathrm{mg} / \mathrm{kg} /$ die, max. $1 \mathrm{~g} /$ die, 3 napon keresztül) indítunk, melyet alacsony dózisú per os készítménnyel folytatunk.

Amennyiben a gyulladás helyi kezelés mellett három hónap alatt nem szűnik meg, szisztémás immunszuppresszív terápia, szteroid, illetve betegséglefolyást módosító reumaellenes szerek (DMARD) bevezetése szükséges. Az utóbbiak közül napjainkban is a metotrexát számít a fó kezelési vonalnak JIA-asszociált uveitis esetén. Átlagos heti adagja $15 \mathrm{mg} / \mathrm{m}^{2}$; orálisan, illetve szubkután formában adható, hatása 6-8 hét alatt alakul ki. A terápia hosszú távon biztonsággal alkalmazható, mellékhatásai közül a hányinger, a hasi fájdalom, a szé- dülés, illetve a májenzimértékek emelkedése a leggyakrabban észlelt jelenség [11].

A betegek többségénél a fent részletezett gyógyszeres kezelés ellenére remisszió nem érhető el. Állatkísérletek és humánvizsgálatok is bizonyították a tumornekrózisfaktor-alfa $(\mathrm{TNF} \alpha)$ szerepét a kórkép patogenezisében, mely lehetővé tette a célspecifikus terápiák, a TNF $\alpha$ blokkoló biologikumok (például adalimumab-, infliximabinjekció) bevezetését. Ezek hatásosságát egy 2014es metaanalízis is alátámasztja [12]. A legelterjedtebb adalimumabkezelést szubkután formában kéthetente alkalmazzuk a testsúlykilogramm függvényében. Az infliximab intravénás formában adható. A TNF $\alpha$-blokkolók monoterápiában is eredményesek, de az adalimumabkezelés metotrexáttal történt kombinációja során csökkent, adalimumab elleni antitestszint volt kimutatható, magyarázva a kombinált gyógykezelés hatékonyabb voltát [13]. Kiemelendő, hogy a JIA terápiájában elterjedt TNF $\alpha$-blokkoló etanerceptinjekció adása mellett uveitis kialakulásáról vagy fellángolásáról számoltak be, ami hangsúlyozza a biológiai terápiás készítmények alkalmazásakor is a rendszeres szemészeti szakvizsgálatok fontosságát [14-16].

A biologikum bevezetése előtt ki kell zárni aktív vagy latens tuberkulózis jelenlétét, aktív fertőzések fennállását (hepatitis B, C), demyelinisatiós betegségeket, szisztémás autoimmun kórképeket (SLE). A kezelés leggyakoribb mellékhatásaként a lokális bőrreakciók (bőrpír, duzzanat) mellett gyakoribb felső légúti fertőzések jelentkezhetnek. Súlyos fertőzés kialakulása nagyon ritka, s nem észlelték a malignus betegségek kialakulásának fokozott kockázatát sem [12].

\section{Vizsgálatunk}

Retrospektív vizsgálatunk során a 2013. január l-tól 2018. január 1-ig tartó időszakban a Pécsi Tudományegyetem Gyermekgyógyászati és Szemészeti Klinikáján uveitisszel kezelt gyermekek adatait elemeztük. Az adatgyüjtés az e-MedSolution betegnyilvántartó rendszerből történt. Kutatásunkat a Pécsi Tudományegyetem Regionális Etikai Bizottsága jóváhagyta.

A vizsgálatba beválasztott 33 gyermek átlagos életkora az uveitis diagnózisakor 9,3 (0,3-17,8) év volt. Nemi megoszlásuk közel azonos volt (16 leány, 17 fiú), de JIA-hez társult uveitis esetén enyhe női túlsúly volt észlelhető (8 leány, 5 fiú).

A gyulladás lokalizációja alapján az anterior uveitis volt a leggyakoribb $(66 \%, 22 / 33)$, ezt követte a posterior $(21 \%, 7 / 33)$; sporadikusan fordult elő anterior-intermedier $(10 \%, 3 / 33)$, illetve intermedier forma $(3 \%, 1 / 33)$.

A gyermekek közel felénél $(45 \%, 15 / 33)$ szisztémás autoimmun kórkép igazolódott. Betegeink nagy részénél $(36 \%, 12 / 33)$ JIA állt a háttérben, két gyermeknél $(6 \%, 2 / 33)$ Behcet-kórhoz, egy betegünknél $(3 \%, 1 / 33)$ gyulladásos bélbetegséghez (IBD) társult az uveitis. 5 betegnél $(15 \%, 5 / 33)$ infekció volt a kiváltó tényező, 
két-két esetben $(6-6 \%, 2 / 33-2 / 33)$ Toxocara és Toxoplasma gondii, egy esetben $(3 \%, 1 / 33)$ pedig Borreliafertőzés igazolódott. Betegeink jelentős hányadában $(40 \%, 13 / 33)$ diagnosztikus vizsgálatainkkal nem volt kimutatható autoimmun kórkép vagy fertőzés, az uveitis idiopathiásnak bizonyult.

Az etiológia és az anatómiai lokalizáció összefüggését tekintve a szisztémás autoimmun betegségekhez (JIA, IBD, Behcet-kór) társult uveitis kizárólag anterior lokalizációban fordult elő. Azon betegeknél, akiknél fertőzés igazolódott, kizárólag posterior uveitist találtunk. Az anterior-intermedier és intermedier uveitisek idiopathiásak voltak.

Vizsgálatunkban a JIA diagnózisa és az uveitis diagnózisának felállítása között átlagosan 2,5 (0-11,5) év telt el. Egy gyermeknél az uveitis az ízületi tünetek után 11,5 évvel alakult ki. Fontos kiemelni, hogy két JIA-betegünk esetében a szemészeti gyulladás már az ízületi tünetek megjelenése előtt jelentkezett.

Azoknál a betegeinknél, akik immunológiai gondozás alá kerültek, a hazai és nemzetközi terápiás irányelveket követtük. A lokális szemészeti kezelés mellett 3 gyermek az uveitis vagy a társuló alapbetegség súlyossága miatt szisztémás szteroidot kapott. DMARD-kezelésként metotrexát 18 páciensnél került bevezetésre, 8 betegnél tartós remissziót sikerült elérni, 10 betegnél relapsus jelentkezett. Egy beteg graviditás miatt azatioprinterápiában részesült. A fenti gyógyszerek alkalmazása mellett 13 gyermeknél (8 JIA-asszociált, három idiopathiás, két Behcet-kórhoz társuló uveitis) tartós remissziót nem értünk el, ezért TNF $\alpha$-blokkoló biológiai terápiát, szubkután adott adalimumabinjekciót vezettünk be. A kezelés megkezdését követően átlagosan $1,45(0,75-2,5)$ hónapon belül 12 betegnél teljes, egy betegnél részleges remissziót észleltünk. Átmeneti, lokális bőrreakció nem alakult ki.

\section{Megbeszélés}

Az uveitis ritka betegség, ám kiemelt jelentőséggel bír, súlyos szemészeti maradványtüneteket okozhat. A gyermekkori uveitisre jellemző, hogy a lefolyás általában súlyosabb, mint felnőttkorban. Európában a vaksághoz vezető okok között az 5. helyen áll [1]. A gyermekkori esetek nagy része már a szemészeti szövődmények, gyakran maradványtünetek megjelenésekor kerül diagnosztizálásra. A kórisme megfelelő időben történő felállításának elmaradása a gyakran tünetmentes betegségkezdet mellett az életkori sajátosságokból adódó diagnosztikai nehézségekkel magyarázható. A gyermekek nem vagy csak kevésbé tudják jelezni a látásromlást szüleiknek vagy a kezelőorvosnak, ezért a rendszeres szemészeti vizsgálat nélkülözhetetlen a betegség nyomon követéséhez [17].

Beteganyagunkban az uveitis anatómiai lokalizációját illetően a nemzetközi összehasonlító tanulmányokban leírt arányokat $[18,19]$ találtuk. Eseteink többsége ante- rior uveitis volt, kisebb arányban észleltünk posterior, anterior-intermedier és intermedier uveitist.

A betegség etiológiáját tekintve adataink a nemzetközi irodalomban leírtakkal csaknem megegyeztek. A gyermekek közel felénél szisztémás autoimmun betegséghez asszociáltan jelentkező, döntő többségben JIA-hez társult eseteket láttunk. Irodalmi adat, hogy a JIA leggyakoribb és potenciálisan legkárosabb extraarticularis manifesztációja az uveitis [20].

A szisztémás autoimmun betegségben szenvedő, szemészetileg tünetmentes gyermekek uveitis irányában történő rendszeres szemészeti szürővizsgálata elengedhetetlen része a beteggondozásnak. A JIA-asszociált szemészeti szövődmények jelentkezésének pontos ideje nem jósolható meg. Egy betegünk esetében több mint egy évtizeddel az ízületi gyulladás megjelenése után alakult ki az uveitis, emellett olyan esetet is észleltünk, amikor a szemészeti eltérés megelőzte a szisztémás autoimmun betegség egyéb tüneteinek jelentkezését, elősegítve ezzel annak korai diagnózisát. A nemzetközi irodalmi adatoknak megfelelően JIA-pácienseink esetében átlagosan 2,5 $(0-11,5)$ év telt el a JIA diagnózisa és az uveitis diagnózisának felállítása között $[21,22]$. Véleményünk szerint gondozott betegeink esetén a rendszeres szemészeti szakvizsgálatoknak kiemelt szerepük volt az uveitis korai diagnosztizálásában, lehetővé téve ezáltal az adekvát terápia alkalmazását, melynek segítségével a szemészeti szövődmények sok esetben elkerülhetők voltak.

Az anatómiai lokalizáció és az etiológiai faktorok öszszefüggését tekintve a gyermekkori uveitisek többségét adó anterior uveitisek nagy része szisztémás autoimmun betegséghez társultan jelentkezett, míg a posterior uveitisek hátterében jellemzőbben találtunk infekciót.

Számos tanulmány vizsgálta a gyermekkori uveitisben alkalmazott különböző gyógyszeres kezelések hatékonyságát. A nemzetközi vizsgálatok hangsúlyozták a TNF $\alpha$ blokkolók hatásosságát JIA-asszociált uveitis esetén [20]. Az általunk gondozott gyermekeknél az ajánlásoknak megfelelően tartós immunszuppresszív DMARDterápia ellenére fennálló betegségaktivitás észlelésekor biologikum bevezetése történt. Az anti-TNF $\alpha$ szer hatékonynak bizonyult, mellékhatás jelentkezését nem észleltük, a nemzetközi irodalomban leírt kedvező kimenetel a klinikánkon gondozott betegcsoport esetében is igazolódott.

Tanulmányunkkal alátámasztjuk, hogy a gyermekkorban diagnosztizált autoimmun betegség esetén uveitis irányában történő szemészeti szakvizsgálat rendkívül fontos. Uveitis észlelésekor a háttérben álló kórok felderítése miatt gyermekgyógyászati szakvizsgálat javasolt, melyhez a társszakmák szoros együttmúködése nélkülözhetetlen.

Anyagi támogatás: A kézirat megírása anyagi támogatásban nem részesült. 
Szerzôi munkamegosztás: K. J. A kézirat megfogalmazója. Részt vett a betegek adatainak összegyüjtésében, feldolgozásában. M. B. dolgozta ki vizsgálatunk célját, munkánk során az általa vizsgált és immunológiai gondozása alatt álló betegek adatait dolgoztuk fel. M. B. végezte a betegek részletes kivizsgálását, rendszeres kontrollvizsgálatait, a terápia koordinálását, ezt követően az adatok gyüjtését, feldolgozását, összegzését. A kézirat megírása során is nélkülözhetetlen segítséget nyújtott. G. V. végezte a betegek rendszeres szemészeti szakvizsgálatát, gondozását. A kézirat megfogalmazása során a szemészeti szakterület kérdéseiben segített. Ny. Z. az infekciós eredetű uveitises betegek kezelésében vett részt, illetve a kézirat megfogalmazása során szakmai tanáccsal látott el. A cikk végleges változatát valamennyi szerző elolvasta és jóváhagyta.

\section{Érdekeltségek: A szerzőknek nincsenek érdekeltségeik.}

\section{Irodalom}

[1] Tugal-Tutkun I. Pediatric uveitis. J Ophthalmic Vis Res. 2011; 6: 259-269.

[2] Sohár N. Pediatric uveitis. [Gyermekkori uveitisek.] Szemészet 2017; 154: 191-198. [Hungarian]

[3] Kalinina Ayuso V, Makhotkina N, van Tent-Hoeve M, et al. Pathogenesis of juvenile idiopathic arthritis associated uveitis: the known and unknown. Surv Ophthalmol. 2014; 59: 517531.

[4] Saurenmann RK, Levin AV, Feldman BM, et al. Prevalence, risk factors, and outcome of uveitis in juvenile idiopathic arthritis: a long-term followup study. Arthritis Rheum. 2007; 56: 647-657.

[5] Vitale AT, Graham E, de Boer JH. Juvenile idiopathic arthritisassociated uveitis: clinical features and complications, risk factors for severe course, and visual outcome. Ocul Immunol Inflamm. 2013; $21: 478-485$

[6] Vastert SJ, Bhat P, Goldstein DA. Pathophysiology of JIA-associated uveitis. Ocul Immunol Inflamm. 2014; 22: 414-423.

[7] Dohán J. Pediatric uveitis: features, screening and care. [Gyermekkori uveitis: jellemzők, szúrés és gondozás.] Gyermekgyógy Továbbk Szle. 2011; 16: 169-171. [Hungarian]

[8] Dohán J. Pediatric uveitis and its therapy. [Gyermekkori uveitisek és kezelésük.] Orvosképzés 2014; 89: 39-41. [Hungarian]

[9] Lee RW, Dick AD. Current concepts and future directions in the pathogenesis and treatment of non-infectious intraocular inflammation. Eye 2012; 26: 17-28.
[10] Heiligenhaus A, Michels H, Schumacher C, et al. Evidence based, interdisciplinary guidelines for anti-inflammatory treatment of uveitis associated with juvenile idiopathic arthritis. Rheumatol Int. 2012; 32: 1121-1133.

[11] Bou R, Iglesias E, Antón J. Treatment of uveitis associated with juvenile idiopathic arthritis. Curr Rheumatol Rep. 2014; 16: $437-444$.

[12] Simonini G, Druce K, Cimaz R, et al. Current evidence of antitumor necrosis factor $\alpha$ treatment efficacy in childhood chronic uveitis: a systematic review and meta-analysis approach of individual drugs. Arthritis Care Res. 2014; 66: 1073-1084.

[13] Ramanan AV, Dick AD, Benton D, et al. A randomised controlled trial of the clinical effectiveness, safety and cost-effectiveness of adalimumab in combination with methotrexate for the treatment of juvenile idiopathic arthritis associated uveitis (SYCAMORE trial). Trials 2014; 15: 14-26.

[14] Tynjälä P, Lindahl P, Honkanen V, et al. Infliximab and etanercept in the treatment of chronic uveitis associated with refractory juvenile idiopathic arthritis. Ann Rheum Dis. 2007; 66: 548550.

[15] Saurenmann RK, Levin AV, Feldman BM, et al. Risk of new-onset uveitis in patients with juvenile idiopathic arthritis treated with anti-TNF $\alpha$ agents. J Pediatr. 2006; 149: 833-836.

[16] Lim LL, Fraunfelder FW, Rosenbaum JT. Do tumor necrosis factor inhibitors cause uveitis? A registry-based study. Arthritis Rheum. 2007; 56: 3248-3252.

[17] Sen ES, Dick AD, Ramanan AV. Uveitis associated with juvenile idiopathic arthritis. Natl Rev Rheumatol. 2015; 11: 338-348.

[18] Deschenes J, Murray PI, Rao NA, et al. International Uveitis Study Group (IUSG): clinical classification of uveitis. Ocul Immunol Inflamm. 2008; 16: 1-2.

[19] Jabs DA, Nussenblatt RB, Rosenbaum JT, et al. Standardization of uveitis nomenclature for reporting clinical data. Results of the First International Workshop. Am J Ophthalmol. 2005; 140: 509-516.

[20] Constantin T, Foeldvari I, Anton J, et al. Consensus-based recommendations for the management of uveitis associated with juvenile idiopathic arthritis: the SHARE initiative. Ann Rheum Dis. 2018; 77: 1107-1117.

[21] Heiligenhaus A, Niewerth M, Ganser G, et al. Prevalence and complications of uveitis in juvenile idiopathic arthritis in a population-based nation-wide study in Germany: suggested modification of the current screening guidelines. Rheumatology 2007; 46: 1015-1019.

[22] Cosickic A, Halilbasic M, Selimovic A, et al. Uveitis associated with juvenile idiopathic arthritis, our observations. Med Arch. 2017; 71: 52-55.

(Kiss Judit dr.,

Pécs, Esztergár Lajos u. 5/A, 1/1., 7633 e-mail: judith.kiss@gmail.com)

A cikk a Creative Commons Attribution 4.0 International License (https://creativecommons.org/licenses/by/4.0/) feltételei szerint publikált Open Access közlemény, melynek szellemében a cikk bármilyen médiumban szabadon felhasználható, megosztható és újraközölhető, feltéve, hogy az eredeti szerző és a közlés helye, illetve a CC License linkje és az esetlegesen végrehajtott módosítások feltüntetésre kerülnek. (SID_1) 